\title{
Hydrodynamic conditions associated with the formation, maintenance and dissipation of a phytoplankton thin layer in a coastal upwelling system
}

\author{
Lourdes Velo-Suárez ${ }^{a}{ }^{*}$, Liam Fernand ${ }^{b}$, Patrick Gentien $^{c}$ and Beatriz Reguera ${ }^{a}$ \\ a Instituto Español de Oceanografía, Centro Oceanográfico de Vigo, Aptdo 1552, E-36200 Vigo, Spain \\ ${ }^{\mathrm{b}}$ Centre for Environment Fisheries and Aquaculture Science (CEFAS), Pakefield Rd., Lowestoft, Suffolk, N R33 \\ OHT, UK \\ ${ }^{c}$ IFREMER, Centre de Brest. DYNECO. Pointe du Diable BP70, 29280 Plouzane, France \\ *: Corresponding author : Lourdes Velo-Suárez, Tel.: +34 986 492111; fax: +34 986 498626, email address : \\ lourdes.velo@vi.ieo.es
}

\begin{abstract}
:
During May-June 2005, a 17-d cruise was carried out in Ría de Pontevedra (Galician Rías Baixas) to study the physical-biological interactions that may lead to subsurface aggregations of phytoplankton organisms in thin layers (TLs). Physical processes governed the initiation and development, maintenance, and decline of a diatom (toxin producing Pseudo-nitzschia spp. and Chaetoceros socialis) TL during an upwelling relaxation-upwelling-downwelling sequence. Differences in shear profiles appeared to lead to the formation of a TL during upwelling events. These results reveal that the coupling between maximum values of shear and buoyancy frequency can shape a subsurface chlorophyll maximum (SCM) into a TL. The effect of shear upon phytoplankton patches, which has been predicted on the basis of theoretical studies, has been corroborated in this study in which the vertical distribution of an observed TL was controlled by physical processes.

Understanding both local fine-scale circulation patterns and regional physical processes will improve our knowledge of the spatial and temporal occurrence of these layers. Results here bring new understanding in TL dynamics at coastal upwelling sites and provide information about the physical processes involved in TL development, which can be used to predict their occurrence and understand their ecological implications.
\end{abstract}

Keywords: Thin layer; Phytoplankton; Shear; Coastal upwelling system; Physical forcing; Coastal circulation 


\section{Introduction}

Spatial heterogeneity or "patchiness" in plankton distributions is one of the oldest oceanographic observations reported. A phytoplankton patch is defined as a water mass containing a concentration of cells which is several times the background concentration (Bainbridge 1957). Thin layers (TLs) of plankton are coherent and conspicuous heterogeneities in the vertical distribution of marine organisms. These structures were first detected by Strickland (1968) and sampled in detail by Derenbach et al. (1979). In the last two decades, advances in instrumentation and sampling techniques (Donaghay et al. 1992, Gentien et al. 1995, Franks \& Jaffe 2001) have confirmed that phytoplankton TLs occur in a variety of conditions in marine waters (Vilicic et al. 1989, Bjoernsen \&Nielsen 1991, Donaghay et al. 1992, Gentien et al. 1995). These fine structures appear frequently in the water column and can persist for days (Dekshenieks et al. 2001). They range in vertical dimension from centimetres to a few metres, and have been observed to extend horizontally for kilometres (Dekshenieks et al. 2001, Rines et al. 2002).

Significant progress has been made in describing the spatial and temporal scales of TLs and their variability relative to oceanographic forcing in some regions (McManus et al. 2003, Lunven et al. 2005); several empirical studies have revealed strong statistical relationships between plankton TLs and the physical structure of the water column (Dekshenieks et al. 2001). Surveys in East Sound (WA, US) and Monterey Bay (CA, US) have shown that stratification, shear, and regional water mass variability all influence the development and evolution of TLs (McManus et al. 2003, Ryan et al. 2008); TLs have also been found associated with episodic environmental events, such as upwelling-downwelling cycles (Ryan et al. 2008, Velo-Suárez et al. 2008). Although there have been significant advances in this field, there is still a lack of information about the processes involved in TL development, advection and maintenance; this topic is being dealt with by the GEOHAB core research project of "HABs in stratified environments (GEOHAB 2008).

A key question is whether TLS are a passive response of the plankton promoted by physical processes or are developed from active aggregation of the organisms that constitute them. To address this question, several theoretical approaches have been used to explain TL generating mechanisms. Franks (1992) examined the importance of buoyancy forces to maintain the position of phytoplankton organisms along a particular isopycnal. Later, the same author (Franks 1995) proposed a shear-driven mechanism for layer formation based on the interaction between internal waves and phytoplankton patches. Gallager et al. (2004) and Genin et al. (2005) invoked the swimming behaviour of some dinoflagellates and zooplankton to explain TL development and maintenance. Stacey et al. (2007) discussed the effects of turbulent dissipation combined with three TL-convergence mechanisms: straining (vertical shear of the horizontal current), motility and buoyancy. Recently developed models on TL formation point towards vertically sheared horizontal currents as the main factor involved in their development (Birch et al. 2008). Durham et al. 2009 has also proposed the coupled action of phytoplankton motility and horizontal shear as a TL formation mechanism (gyrotactic trapping).

TLs are a significant source of small-scale vertical heterogeneity in the marine environment. Development of phytoplankton TLs influences coastal ocean ecological processes in many ways. They may provide a mechanism for the long-term maintenance and sudden expression of harmful algae blooms (HABs). The onset of a bloom can remain undetected since HAB populations may be concentrated in a discrete TL that can easily be missed by conventional sampling methods used in monitoring programmes (Bjørnsen \& Nielsen 1991, McManus et al. 2008, Velo-Suárez et al. 2008). These structures not only affect optical and acoustical signatures in the sea but also have a significant influence on the dynamics of marine ecosystems. 
Nowadays, models have thus far been restricted by insufficient ability to gauge the interactions between the biology of algal taxa and underlying physical processes. Therefore, it is critical to improve our ability to understand the spatio-temporal dynamics of these structures in coastal environments at the appropriate scales.

During spring 2005, a two-week multidisciplinary cruise was conducted to describe the fine-scale physical and biological structure of the water column and to explore the occurrence of TLs of harmful microalgae in Ría de Pontevedra (Galicia, northwest Spain). Studies were carried out on board R/V Mytilus from 31 May to 14 June 2005. The phytoplankton assemblages and the physical-biological interactions in Ría de Pontevedra during the study are described in an earlier publication (Velo Suárez et al. 2008). Here we focus on the fine-scale optical and physical structure of the water column and its relation with the distribution of microplankton at a fixed sampling station during the cruise. The onset, maintenance and dispersion of a TL in an upwelling prevalent period followed by upwelling relaxation conditions in the Ría are described. In this work, thin phytoplankton layers were identified from chlorophyll fluorescence data measured by sensors on the high resolution profilers, using the criteria detailed in Dekshenieks et al (2001): 'For a structure to be considered a thin layer, the chlorophyll profile has to meet 3 criteria. (1) The feature has to be $\leq 5 \mathrm{~m}$ thick; this is below the scale routinely sampled with bottles and nets on most oceanographic cruises. Layer thickness is measured where the optical signal was at half maximum intensity. (2) The optical signal has to be present in 2 or more sequential profiles. (3) The optical signal has to be at least 3 times greater than background. These criteria are conservative and effectively eliminate ephemeral features' (Dekshenieks et al. 2001).

\section{Material and methods}

\subsection{The study area}

Ría de Pontevedra is a flooded tectonic valley located on the NW coast of the Iberian Peninsula (Fig. 1). This Ría has a surface of $141 \mathrm{~km} 2$, a mean depth of $31 \mathrm{~m}$ and a volume of $3.5 \mathrm{~km} 3$. Hydrodynamics of the Ría is mainly driven by freshwater inputs and the wind regime (Prego et al. 2001). Tidal forcing appears to be a minor factor since wind speeds higher than $4 \mathrm{~m} \mathrm{~s}-1$ reverse surface currents against the tide (De Castro et al. 2000). The Lérez River (Fig. 1) provides the main freshwater input; its monthly discharge rate ranges from 2 to $80 \mathrm{~m} 3 \mathrm{~s}-1$ and closely follows rain patterns (GómezGesteira et al 2000).

Northerly winds promote upwelling of cold, salty and nutrient-rich Eastern North Atlantic Central Water (ENACW) from spring to early autumn (March to October). Upwelling forces a two-layer density-induced positive circulation, characterized by the outflow of surface water and the compensating inflow of upwelled waters at the bottom (Wooster et al. 1976). In autumn and winter (October to March) southerly winds are predominant in the area and the circulation reverses. Shelf water enters the Ría at the surface and there is a compensating outflow at the bottom (Prego et al. 2001). Changes in wind forcing lead to rapid changes ( $<24 \mathrm{~h}$; Sousa 1995) in the oceanographic conditions of the Ría, which in turn force significant changes in plankton distribution and ecology (Tilstone et al. 2000; 2003).

\subsection{Sampling overview}

Fine-scale profiles of biological and physical structure were simultaneously measured at a fixed $45 \mathrm{~m}$ deep station (st. 2$)$, located in the navigation channel $\left(42^{\circ} 21.38^{\prime} \mathrm{N}, 8^{\circ}\right.$ 
50.07'W), during the whole survey (Fig. 1). Its position makes it suitable for evaluating and averaging of the main processes that take place in the system due to changes in external forcing factors (Nogueira et al. 1997).

Daily measurements were carried out during the cruise with the high-resolution IFREMER particle size analyzer profiler (IPSAP), which includes a SBE 25 CTD Probe (Sea-Bird Electronics, Washington, USA), a fluorescence sensor (Seapoint Sensors, Inc., Exeter, New Hampshire, USA), and a particle size analyser (CILAS, Orléans, France). The sensor for photosynthetically active radiation (PAR) measurements was a LICOR Spherical SPQA. The IPSAP profiler provides a synchronized set of data in real time (Gentien et al. 1995, Kononen et al 2003, Velo-Suárez et al 2008); it allows real time data acquisition at $5 \mathrm{~Hz}$ of standard parameters, such as depth, temperature, salinity and chlorophyll-like in vivo fluorescence PAR. The CTD fluorometer was calibrated with laboratory cultures of the diatom Chaetoceros gracile using the trichromatic method for chlorophyll determination according to Aminot \& Kerouel (2004). IPSAP data were post-processed averaging every $50 \mathrm{~cm}$. Data used hereafter are $50 \mathrm{~cm}$ averaged without overlap. The IPSAP profiler was lowered at a speed of 0.3 $\mathrm{m} \mathrm{s}^{-1}$, allowing an accurate assessment of the hydrological characteristics of the water column and the detection of water layers with distinct characteristics.

\subsection{Wind measurements}

Hourly mean values of wind speed and direction were obtained from the Seawatch (Oceanor) buoy off Cabo Silleiro (www.puertos.es; Fig. 1) (42 $7.8^{\prime} \mathrm{N}, 9^{\circ} 23.4^{\prime} \mathrm{W}$ ). Although wind-induced circulation patterns are highly influenced by local orography in the Ría, this site is representative for winds blowing off the Ría Baixas (Herrera et al. 2005).

\subsection{Current measurements}

Current velocity profiles were measured continuously at station 2 with a bottommounted ADCP (RD Instruments, $614.4 \mathrm{kHz}$ ) moored from 30 May-13 June 2005. Reported current velocities are based on 2 min averages (bin size: $1 \mathrm{~m}$ ) from raw ADCP data processed using WinADCP software (RD Instruments). ADCP distance to the surface was estimated by post-processing the echo amplitude profile of pings (Visbeck, 2002).

Current data were filtered using a pl64 filter (Limeburner 1985) with a half-amplitude period of $33 \mathrm{~h}$ and a half-power period of $38 \mathrm{~h}$ (for visualizing progressive vector diagrams, PVD, only). The filter removes energy at periods shorter than $38 \mathrm{~h}$, thus removing tidal, diurnal and inertial signals, while preserving energy at lower frequencies, including the mean current velocity.

\subsection{Physical terms}

To estimate water column stability, different parameters were calculated. The static stability (Brunt-Väisälä frequency, $\mathrm{N}^{2}$ ) was calculated as follows:

$$
\left.\mathrm{N}^{2}=-\left(\frac{\mathrm{g}}{\rho}\right) \frac{\mathrm{d} \rho}{\mathrm{dz}} \quad(\text { radians s})^{-1}\right)^{2},
$$

where $\rho$ is the water density every $0.5 \mathrm{~m}$ (obtained from CTD profiles) and $\mathrm{g}$ is the local acceleration due to gravity. $N^{2}$ expresses the oscillation frequency produced by a 
particle when displaced away from its density equilibrium position; its value increases with increasing density gradients.

The dynamic stability (Richardson Number, $R i$ ) was calculated as a criterion for the relative importance of mechanical and density effects in the water column as follows:

$$
\mathrm{Ri}=\mathrm{N}^{2} /\left(\overline{\frac{\mathrm{du}}{\mathrm{dz}}}\right)^{2}
$$

Density profiles used to estimate $R i$ were taken from IPSAP casts performed in the same time window as the one-hour current velocity data $\left(\mathrm{m} \mathrm{s}^{-1}\right)$ from the moored ADCP used to estimate averaged shear rates $\left(\mathrm{s}^{-1}\right)$. To reduce instrumental error, shear data were averaged on 30 consecutive current ADCP profiles ( 1 hour). When $R i$ is small $(R i<0.25)$, the velocity shear is sufficient to overcome the tendency of a stratified water column to remain stratified.

Under isotropic conditions, ensemble average turbulent kinetic energy dissipation rates ( $\varepsilon$ ) can be estimated from (Stipps, 2005) :

$$
\varepsilon=\frac{15}{2} \sqrt{\left(\frac{\mathrm{du}}{\mathrm{dx}}\right)^{2}}\left(\mathrm{~m}^{2} \mathrm{~s}^{-3}\right),
$$

where $d u / d x$ is the vertical profile of the small-scale current shear in water (Batchelor, 1960) and $v=1.28 \times 10^{-6} \mathrm{~m}^{2} \mathrm{~s}^{-1}$ is the kinematic molecular viscosity of seawater at $15^{\circ} \mathrm{C}$ (Kaye \& Laby 1995). Although isotropic turbulence can be assumed without any restriction in a non-stratified flow, stratified conditions modify the dynamics of turbulence in the water column (Stipps, 2005). Nevertheless, Yamazaki and Osborn (1990) observed that the difference between estimates derived from isotropic and anisotropic formula are small if the following criterion is met:

$$
\frac{\varepsilon}{\nu \mathrm{N}^{2}}>20 \text {. }
$$

Consequently, estimates of vertical shear remain significant and can be used as a proxy of the energy level. These estimates are not suitable to calculate turbulence dissipation rates since small short time scale processes would be missed. Therefore, this paper focuses on changes on a longer time-scale.

The threshold of ADCP shear estimates was calculated from the standard deviation of a single ping (60 $\mathrm{mm} \mathrm{s}^{-1}$ ) provided by the instrument manufacturers (RD Instruments) and the total number of measurements (60) used in the averaging process. Because individual pings are independent, the statistical error of the velocity measurement can be reduced according to the rate between the statistical uncertainty of one ping and the number of pings squared. The minimum root-mean-square shear estimated from this current velocity statistical error was $4 \times 10^{-3} \mathrm{~s}^{-1}$.

Scripts from the FATHOM MATLAB toolbox for Multivariate Ecological \& Oceanographic Data Analysis were used for vector manipulation and plotting.

\section{Results}

\subsection{Response to wind forcing}

Northerly winds prevailed over the shelf from 31 May to 08 June. Wind speed dropped from $7 \mathrm{~m} \mathrm{~s}^{-1}$ to nearly $3 \mathrm{~m} \mathrm{~s}^{-1}$ on 02-03 June. At the end of the survey (09 to 14 June), wind direction changed and southerlies became dominant (Fig. 2a). Since rainfall, and consequently runoff, was extremely low during May-June 2005 (Velo-Suárez et al. 
2008), water movements in the Ría were defined according to the dominant shelf wind. A PVD plot of low-pass filtered current data from the moored ADCP shows the main periods of inflow and outflow at surface and bottom waters from 01 to 14 June (Fig. 2b; Fig 2c). A positive residual circulation was observed on 01 June. From 02 - 03 June, there was a short period of surface inflow and compensating outflow of bottom water in response to northwesterly wind relaxation, Two days later, on 04 June, when northwesterly winds increased, inflow again occurred, this time throughout the whole water column. On 08 June, wind velocity dropped and neither inflow nor outflow was observed. After that, on 09 June, there was a shift to southerly winds of moderate intensity $\left(<3 \mathrm{~m} \mathrm{~s}^{-1}\right)$, and a reversal of the typical upwelling circulation pattern. Three different situations were identified from each hydrodynamic regime and are examined in detail, hereafter referred to as cases $1-3$ (Table 1). Transitional days were

also considered to understand observed changes within the water column.

\subsection{Physical environment and TL onset, maintenance and dispersion}

Attributes of the Chlorophyll a $(\mathrm{Chl} \mathrm{a})$ structure found during the survey are presented in Table 2. Thickness of the $\mathrm{Chl}$ a maximum ranged from 4 to $18.5 \mathrm{~m}$ with its minimum in Case 2 (upwelling). Chl a intensity within the structure, quantified from fluorescence profiles, ranged from 3.72 to 13.43 times greater than the background, with an average of 8.71 times greater. Maximum Chl a concentrations ranged between 7.09 and 24.91 $\mu \mathrm{g} \mathrm{Chl} \mathrm{a} \cdot \mathrm{L}^{-1}$. The structure showed a consistent association with local hydrographic conditions during the whole survey. A sequence of daily profiles of chlorophyll and estimated buoyancy frequencies illustrates the relationship of this structure with the pycnocline at which vertical density gradients were enhanced (Fig 4, Fig 5, Fig 6). A description of the $\mathrm{Chl}$ a structure and its evolution with time during the survey is provided in sections 3.2.1, 3.2.2 and 3.2.3..

3.2.1 Case 1. On 02 June, CTD profiles revealed a subsurface Chl a maximum (SCM) located between the 26.9 and $27.1 \sigma_{t}$ isopycnals (Fig. 3; Fig 4). A day later, Chl a values increased and its maximum continued associated with the maximum density gradient in the pycnocline. The SCM was located slightly below the depth were $N^{2}$ was maximum $\left(>2.5 \times 10^{-4}\left(\text { radians } \mathrm{s}^{-1}\right)^{2}\right)$. High shear values below the pycnocline resulted in high values of shear squared and low values of $R i$, i.e. decreased stability below the SCM at the bottom of the pycnocline (Fig 3; Fig 4).

The lower limit of the photic zone is usually assumed to correspond to the depth at which light equals $1 \%$ of surface illumination. During Case 1 , the light available in the upper part of the SCM (6-7 m depth) was high (ca. 20\%) but its lower part (17-14 m) was located below the $1 \%$ of the incident radiation (Table 2 ).

3.2.2 Case 2. On 06 June, the SCM became thinner $(<5 \mathrm{~m})$ and had a better spatial definition (Fig 5, Table 2). Several profiles from other sampling stations confirmed the horizontal extension of the layer in the whole Ría (Velo-Suárez et al. 2008). At this moment this structure could be considered a TL following the criteria of Deksheniek et al (2001). The upwelling event promoted the inflow of ENACW waters at the bottom of the TL located at the pycnocline (Table 2). However, on 08 June, relaxation of northerly winds promoted the vertical displacement of the layer (from 6-10 m to 9-13 m). An

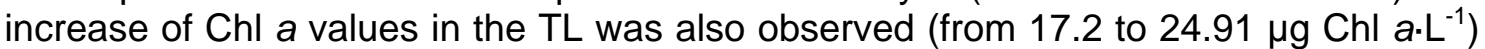
(Table 2), coincident with maximum values of $N^{2}\left(0.8 \times 10^{-4}\left(\text { radians } \mathrm{s}^{-1}\right)^{2}\right)$ in the water column (Fig 5). The TL location during this Case was at the layer of maximum buoyancy frequency $\left.\left(6 \times 10^{-4} \text { (radians } \mathrm{s}^{-1}\right)^{2}\right)$. During this period the water column remained significantly more stratified and stable (high $\mathrm{Ri}$ ) (Fig 5). Nevertheless, lower values of $R i$ were found associated with increased shear and mixing at the base of the 
layer. The TL was associated with the maximum shear in the water column (Fig 3) and its thickness determined by that of the maximum shear region $\left(-0.025\right.$ to $\left.0.025 \mathrm{~s}^{-1}\right)$ Minimum values of shear squared were found below the $27.1 \sigma_{t}$ isopycnal during the upwelling pulses (Fig 3). Light availability at the upper part of the TL was significantly lower during Case 2 than in the upper part of the SCM on 2-3 June (Table 2), but did not reach the limit of $1 \%$ at the lower boundary of the TL during this period.

3.2.3 Case 3. Downwelling favourable winds after 08 June resulted in the broadening of the SCM (from $4 \mathrm{~m}$ to $10.5 \mathrm{~m}$ width) and its final displacement to the bottom at the end of the survey (Fig 6, Table 2). These events coincided with the weakening and disappearance of the stepped structure in the pycnocline and the lowest values of $N^{2}$ found during the survey (Fig 6, Table 2). Increased levels of shear and low values of $R i$ (high instability) at the bottom, where the SCM was being displaced, were observed (Fig 6). High turbulence dissipation rates in the bottom layers also increased when downwelling started (Fig 3).

On 13 June, a new strong density discontinuity at $10 \mathrm{~m}$ depth appeared due to the intrusion of downwelled waters $\left(16^{\circ} \mathrm{C}\right)$. However, a secondary $N^{2}$ maximum $\left(27.1 \sigma_{t}\right)$ was also observed at $25 \mathrm{~m}$ where the TL was located before (Fig 6). During this period, light availability became progressively lower in the upper part of the structure $(<6 \%)$ and no more than the $1 \%$ of the incident light was available in its lower boundary (Table 2).

\subsection{Relationship between the TL and the shear structure}

The thickness of the observed $\mathrm{Chl}$ a structure during the survey was found to be related to the velocity field that promoted different kinds of shear profiles. During case 1 and

case 3, the SCM was located within or adjacent to a change in the direction of horizontal velocity in a layer of no-motion (between inflowing and outflowing water) (Fig 7). On the other hand, during case 2 the whole water column was found to move in the same direction (inflow). However, vertical heterogeneities in the horizontal velocity promoted the formation of a thin shear region where the SCM was located.

Changes in the shear profile in Case 1 to Case 3 resulted in changes in the Chl a peak intensity and thickness from medium thick to thinner, then medium-thick and finally displace downwards and dispersed (Fig 3; Fig 4).

\section{Discussion}

Results from this study clearly show a direct effect of physical processes on the formation and characteristics of a TL in Ría de Pontevedra. Physical processes mainly governed the maintenance of a TL during the upwelling pulse and its previous formation from a broad $\mathrm{Chl}$ a maximum located at the pycnocline. Similar results have been observed related to phytoplankton and zooplankton TLs in East Sound (Washington, US) (Dekshenieks et al. 2001, Rines et al. 2002, McManus et al. 2003) and in Monterey Bay (California, US) (McManus et al. 2005, Ryan et al. 2008). TLs found in these studies were strongly related to the physical structure of the water column and were detected at both the base of the pycnocline and in weaker gradients in the vertical density structure of the water column. The present study, in agreement with results from East Sound (Dekshenieks et al. 2001), shows that TLs associated with the pycnocline were located in the stratified region of the water column where $N^{2}$ was highest and $R i>0.25$. In general, water columns where $R i$ is below 0.25 , are expected to be unstable and unsuitable for TL development (Dekshenieks et al 2001, 
Pinkel \& Anderson 1997a, 1997b). Results reported here support the evidence that TLs can persist only in regions where buoyancy is sufficient to suppress turbulent flow (Dekshenieks et al. 2001).

The effect of shear on TL thickness during an upwelling event is also documented. Franks (1995), and more recently Stacey et al. (2007) and Birch et al. (2008) have proposed a theoretical model according to which a phytoplankton patch can be strained and thinned by vertical shear and transformed into a TL. We find that from the beginning to the end of the survey, the $\mathrm{Chl}$ a maximum was located at the transition between two flow regimes. However, the $\mathrm{Chl}$ a maximum, located in the no-motion layer (between outflowing and inflowing water masses), was more than $5 \mathrm{~m}$ thick during Case 1 (02-03 June). Wind changes after 03 June promoted the appearance of a high shear region due to vertical variation of the horizontal inflow velocity. At this point, the SCM was strained and became a TL. After the upwelling event, the TL was again located in a high-shear (between inflowing and outflowing water masses) region, where current vectors changed direction. Although the TL was located in the no-motion layer, it was affected by the increase of turbulent mixing in the water column. The mixing event acted to reduce the convergence mechanisms that were maintaining the layer at the beginning of the downwelling process, and finally dispersed it by the end of the survey. These results agree with the theoretical conclusions given by Stacey et al. (2007) and by Birch et al. (2008).

In Monterey Bay, Ryan et al. (2008) found a significant correlation between layer thickness and shear, thus, confirming theoretical considerations (Franks 1995, Stacey et al. 2007, Birch et al. 2008). In our case, the phytoplankton patch was always located within the highest shear region in the water column, but the onset of the TL did not take place until after the upwelling pulse. Although this layer was associated with a high shear vertical profile, the pycnocline where the layer was located was stable $(R i>0.25)$ enough to suppress vertical turbulent mixing that could have eroded the layer during Case 2. It can be concluded that the combination of two convergence mechanismsshear-induced straining and buoyancy-played a major role in the formation and maintenance of the TL during the upwelling event.

The vertical distribution of the TL was also governed by local circulation patterns and episodic changes in water masses driven by wind and tidal forcing. Relaxation and downwelling conditions in the Ría promoted the deepening of the TL on 08 June. Dekshenieks et al. (2001) and Rines et al. (2002) have also observed displacement of phytoplankton TLs and the pycnocline to greater depths after the onset of northerly winds that caused advection of low-salinity waters into East Sound. However, in contrast with results presented here, TLs observed in those studies were not dispersed and persisted in deep waters for days. Here, increased values of turbulent mixing in the whole water column due to relaxation and downwelling seem to have caused the thickening and dissipation of the TL.

Examples of biological processes that may influence the formation of TLs include swimming, cellular division, grazing deterrence and increased water viscosity due to plankton exudates. Extensive observations (Gallager et al. 2004, Genin et al. 2005, Sullivan et al. 2009) have shown that motile plankton species can actively lead to TL formation as the cells aggregate in optimal depths (i.e. pycnocline, nutricline) within the water column. The TL observed in Ría de Pontevedra - mainly formed by nonswimming diatoms Pseudo-nitszchia spp. and Chaetoceros socialis-remained in the pycnocline throughout the upwelling event (Velo-Suárez et al. 2008). Some diatom species have been found to control their buoyancy to regulate their position in the water column (Villareal et al. 1993). Nevertheless, the TL observed in this study was embedded in the pycnocline during the whole survey, and neither positive nor passive vertical migration can be claimed as mechanisms that lead to its development. However, $C$. socialis is known to form aggregates that could have increased the local viscosity and therefore decrease the turbulent diffusion within the observed TL (Jenkinson \& Biddanda 1995). 
On 08 June, higher values of shear squared observed at the base of the pycnocline may have enhanced nutrient diffusion and mixing from bottom waters to the TL located in the pycnocline. Increased nutrient availability together with appropriate light levels in this layer may have promoted growth of the existing diatom population. This could explain the high $\mathrm{Chl}$ a levels found on 08 June together with the eroded base of the layer at that moment. Nutrient concentrations during the survey showed the typical nutrient distribution of upwelling systems, with high concentration of dissolved inorganic nitrogen, phosphates and silicates in bottom waters, lower concentrations at the pycnocline and depleted surface waters (Velo-Suárez et al 2008). This phenomenon has previously been described by Sharples et al. (2001) in stratified waters in the Western English Channel. In that case, turbulent mixing in the bottom layers was observed to supply new nitrate to the pycnocline, and thus, to promote new production and a decline in cell numbers by entraining them into the bottom water masses.

Results from this study show that stratification, shear, turbulence suppression and regional water mass variability in a coastal upwelling system has a strong influence in the development and spatio-temporal dynamics of TLs, and most likely these structures are a common phenomenon in these systems.

\section{Conclusions}

Physical processes governed the initiation and development, maintenance and decline of a TL during a two-week survey in the Ría de Pontevedra. The SCM was always associated with the depth of maximum shear and differences in shear profiles led to the formation of a thin layer during the upwelling event. The effect of shear upon phytoplankton patches, which had been predicted on the basis of theoretical studies, has been corroborated in this study. Although the TL was associated with maximum vertical shear, high values of $\mathrm{N}^{2}$ indicated that this region was sufficiently stable to suppress turbulent vertical mixing that would have dissipated it.

The vertical distribution of the observed TL in this study was controlled by physical processes.

Understanding both local fine-scale circulation and regional mesoscale patterns will improve our knowledge of the spatial and temporal occurrence of these layers. Results here bring new understanding in TL dynamics at coastal upwelling sites and provide information about the physical processes involved in TL development, which can be used to predict their occurrence and understand their ecological implications.

\section{Acknowledgements}

We thank the crew of $R / V$ Mytilus for their help and M.M. Daniélou and I. Ramilo for technical assistance. We are also grateful to the Ecosystem Interactions team at CEFAS. This work was funded by the EU HABIT project (EC 6FP, GOCE-CT-2005003932) and the Spanish TURDIRRIAS project (CTM2006-13884-CO2-02/MAR). This is a contribution to the GEOHAB programme, Core Research Project on HABs in Stratified

Systems. 


\section{Literatured cited}

Aminot, A., Kerouel, R., 2004. Hydrologie des écosystèmes marins. Paramètres et analyses. In: Ifremer (ed) Ifremer, Plouzané, France, 336 pp.

Bainbridge, R., 1957. The size, shape, and density of marine phytoplankton concentrations. Biological Reviews 32, 91-115.

Batchelor, G.K., 1960. The theory of homogeneneous turbulence. Cambridge University Press, Cambridge, U.K.

Bjørnsen, P.K., Nielsen, T.G., 1991. Decimeter scale heterogeneity in the plankton during a pycnocline bloom of Gyrodinium aureolum. Marine Ecology Progress Series 73, 263-267.

Birch, D.A., Young, W.R., Franks, P.J.S. 2008. Thin layers: Formation by shear and death by diffusion. Deep Sea Research Part I 55, 277-295.

De Castro, M., Gómez-Gesteira, M., Prego, R., Taboada, J.J., Montero, P., Herbello, P., Pérez-Villar, V. 2000. Wind and tidal influence on water circulation in a Galician Ría (NW Spain). Estuarine Coastal Shelf Science 51, 161-176.

Dekshenieks, M.A., Donaghay, P.L., Sullivan, J.M., Rines, J.E.B., Osborn, T.R., Twardowski, M.S., 2001. Temporal and spatial occurrence of thin phytoplankton layers in relation to physical processes. Marine Ecology Progress Series 223, 61-71.

Derenbach, J.B., Astheimer, H., Hansen, H.P., Leach, H., 1979. Vertical microscale distribution of phytoplankton in relation to the thermocline. Marine Ecology Progress Series 1, 181-193.

Donaghay, P.L., Rines, H.M., Sieburth, J.M., 1992. Simultaneous sampling of fine scale, biological, chemical and physical structure in stratified waters. Archiv Fur Hydrobiologie 36, 97-108.

Durham, W.M., Kessler, J.M., Stocker, R., 2009. Disruption of vertical motility by shear triggers formation of thin layers. Science 323, 1067-1070.

Franks, P.J.S., 1992. Sink or swim- Accumulation of biomass at fronts. Marine Ecology Progress Series 82, 1-12.

Franks, P.J.S., 1995. Thin layers of phytoplankton: A model of formation by near-inertial wave shear. Deep Sea Research Part I 42, 75-91.

Franks, P.J.S., Jaffe, J.S., 2001. Microscale distribution of phytoplankton: initial results from a two imaging fluorometer, OSST. Marine Ecology Progress Series 220, 59-72.

Gallager, S.M., Yamazaki, H., Davis, C.S., 2004. Contribution of fine-scale structure and swimming behaviour to formation of plankton layers on Georges Bank. Marine Ecology Progress Series 267, 27-43.

Genin, A.J., Jaffe, J.S., Reef, R., Richter, C., Franks, P.J.S., 2005. Swimming against the flow: A mechanism of zooplankton aggregation. Science 308, 680-862.

Gentien, P., Lunven, M., Lehaître, M., Duvent, J.L., 1995. In situ depth profiling of particles sizes. Deep Sea Research Part I 42, 1297-1312.

GEOHAB 2008. Global Ecology and Oceanography of HarmfulAlgal Blooms, GEOHAB Core Research Project: HABs in Stratified Systems. Gentien, P., Reguera, B., Yamazaki, H., Fernand, L., Berdalet, E., and Raine, R. (eds.) IOC and SCOR, Paris, France and Newark, Delaware, USA, 59 pp.

Gómez-Gesteira, M., Castro, M. D., Prego, R., Pérez-Villar, V., 2001. An unusual two layered tidal circulation induced by stratification and wind in the Ría of Pontevedra (NW Spain). Estuarine Coastal and Shelf Science, 52, 555-563.

Herrera, J.L., Piedracoba, S., Varela, R.A., Rosón, G., 2005. Spatial analysis of the wind field on the western coast of Galicia (NW Spain) from in situ measurements. Continental Shelf Research, 25, 1728-1748.

Jenkinson, I.R., Biddanda, B.A., 1995. Bulk-phase viscoelastic properties of seawater: relationship with plankton components. Journal of Plankton Research 17(12), 22512274. 
Kaye, G.W.C., Laby, T.H., 1995. Tables of Physical and Chemical Constants $\left(16^{\text {th }}\right.$ ed), Longman, Essex.

Kononen, K., Huttunen, M., Hallfors, S., Gentien, P., Lunven, M., Huttula, T. T., Laanemets, J., Lilover, L., Pavelson, J., Stips, A., 2003. Development of a deep chlorophyll maximum of Heterocapsa triqueta Ehrenb. at the entrance of the Gulf of Finland. Limnology and Oceanography 48, 594-607.

Limeburner, R. (Ed.), 1983. CODE-2: moored array and large-scale data report. WHOI Tech report 85-35. Woods Hole Oceanographic Institution, Woods Hole, MA, p 234.

Lunven, M., Guillaud, J.F., Youènou, A., Crassous, M.P., Berric, R., Le Gall, E., Kérouel, R., Labry, C., Aminot, A., 2005. Nutrient and phytoplankton distribution in the Loire River Plume (Bay of Biscay, France) resolved by a new Fine Scale Sampler. Estuarine Coastal Shelf Science 65, 94-108.

McManus, M.A., Alldredge, A.L., Barnard, A., Boss, E., Case, J., Cowles, T.J., Donaghay, P.L., Eisner, L., Gifford, D.J., Greenlaw, C.F., Herren, C., Holliday, D.V., Johnson, D., MacIntyre, S., McGehee, D., Osborn, T.R., Perry, M.J., Pieper, R., Rines, J.E.B., Smith, D.C., Sullivan, J.M., Talbot, M.K., Twardowski, M.S., Weidemann, A., Zaneveld, J.R.V., 2003. Characteristics, distribution and persistence of thin layers over a 48 hour period. Marine Ecology Progress Series 261, 1-19.

McManus, M.A., Cherinton, O.M., Drake, P.J., Holliday, D.V., Storlazzi, C.D., Donaghay, P.L., Greenlaw, C.F., 2005. Effects of physical processes on structure and transport of thin zooplankton layers in the coastal ocean. Marine Ecology Progress Series 301, 199-215.

McManus, M.A., Kudela R.M., Silver M.V., Steward G.F., Sullivan J.M., Donaghay P.L:, 2008. Cryptic blooms: Are thin layers the missing connection? Estuasries and Coasts 31:396-401.

Nogueira, E., Pérez, F. F., Ríos, A. F., 1997. Seasonal patterns and long-term trends in an estuarine upwelling ecosystem (Ría de Vigo, NW Spain). Estuarine Coastal and Shelf Science 44, 285-300.

Pinkel R., Anderson S., 1997a. Shear, strain and Richardson number variations in the thermocline. Part 1: Statistical description. Journal of Physical Oceanography 27:264281.

Pinkel R., Anderson S., 1997b. Shear, strain and Richardson number variations in the thermocline. Part 2: Modeling mixing. Journal of Physical Oceanography 27:282-290.

Prego, R., Dale, A.W., De Castro, M., Gómez-Gesteira, M., Taboada, J.J., Montero, P., Ruiz-Villareal, M., Pérez-Villar, V., 2001. Hydrography of the Pontevedra Ría: Intraannual spatial and temporal variability in a Galician coastal system (NW Spain). Journal of Geophysical Research 106, 19845-19857.

Rines, J.E.B., Donaghay, P.L., Dekshenieks, M.A., Sullivan, J.M., and Twardowski, M.S., 2002. Thin layers and camouflage: hidden Pseudo-nitzschia spp. (Bacillariophyceae) populations in a fjord in the San Juan Islands, Washington, USA. Marine Ecology Progress Series 225, 123-137.

Ryan, J.P., McManus, M.A., Paduan, J.D., Chavez, F.P., 2008. Phytoplankton thin layers caused by shear in frontal zones of a coastal upwelling system. Marine Ecology Progress Series 354, 21-34.

Sharples, J., Moore, C.M., Rippeth, T.P., Holligan, P.M., Hydes, D.J., Fisher, N.R., Simpson, J.H., 2001. Phytoplankton distribution and survival in the thermocline. Limnology and Oceanography 46, 486-496.

Sousa, F.M ., 1995. Processsos de mesoescala ao largo da costa portuguesa utilizando datos de satélite e observações in situ. PhD thesis, University of Lisbon.

Stacey, M.T., McManus, M.A., Steinbuck, J.V., 2007. Convergences and divergences and thin layer formation and maintenance. Limnology and Oceanography 52, 15231532.

Strickland, J.D.H., 1968. A comparison of profiles of nutrients and chlorophyll concentrations taken from discrete depths and by continuous recording. Limnology and Oceanography 13, 388-391. 
Stipps A 2005. Dissipation measurement theory in Marine Turbulence Theories, Observation and models. Results of the Cartum Project ed Helmut Z Baumert, John Simpson and Jurgen Sünderman. Cambridge University Press, Cambridge, U.K.

Sullivan J.M., Donaghay P.L., Rines J.E.B., in press. Coastal thin layer dynamics: Consequences to biology and optics. Continental Shelf Research doi:10.1016/j.csr.2009.07.009

Tilstone, G.H., Figueiras, F.G., Lorenzo, L.M., Arbones, B., 2003. Phytoplankton composition, photosynthesis and primary production during different hydrographic conditions at the Northwest Iberian upwelling system. Marine Ecology Progress Series 252, 89-104.

Tilstone, G.H., Míguez, B.M., Figueiras, F.G., Fermín, E.G., 2000. Diatom dynamics in a coastal ecosystem affected by upwelling: coupling between species succession, circulation and biogeochemical processes. Marine Ecology Progress Series 205, 2341.

Velo-Suárez, L., González-Gil, S., Gentien, P., Lunven, M., Bechemin, C., Fernand, L., Raine, R., 2008. Thin layers of Pseudo-nitzschia spp. and the fate of Dinophysis acuminata during an upwelling-downwelling cycle in a Galician Ría. Limnology and Oceanography 53(5), 1816-1834.

Vilicic, D., Legovic, T., Zuitic, V., 1989. Vertical distribution of phytoplankton in a stratified estuary. Aquatic Science 51, 31-46.

Villareal, T.A., Altabet, M.A., Culver-Rymsza, K., 1993. Nitrogen transport by vertically migrating diatoms mats in North Pacific Ocean. Nature 363, 709-712.

Visbeck, M., 2002. Deep velocity profiling using lowered acoustic doppler current profilers: bottom track and inverse solutions. Journal of Atmospheric and Oceanic Technology, 19, 794807.

Wooster, W. S., Bakun, A., McClain, D. R., 1976. The seasonal upwelling cycle along the eastern boundary of the north Atlantic. Journal of Marine Research 34, 131141.

Yamazaki, H., and T.R. Osborn 1990 Dissipation estimates for stratified turbulence. J Geophys. Res., 95, 9379-9744. 


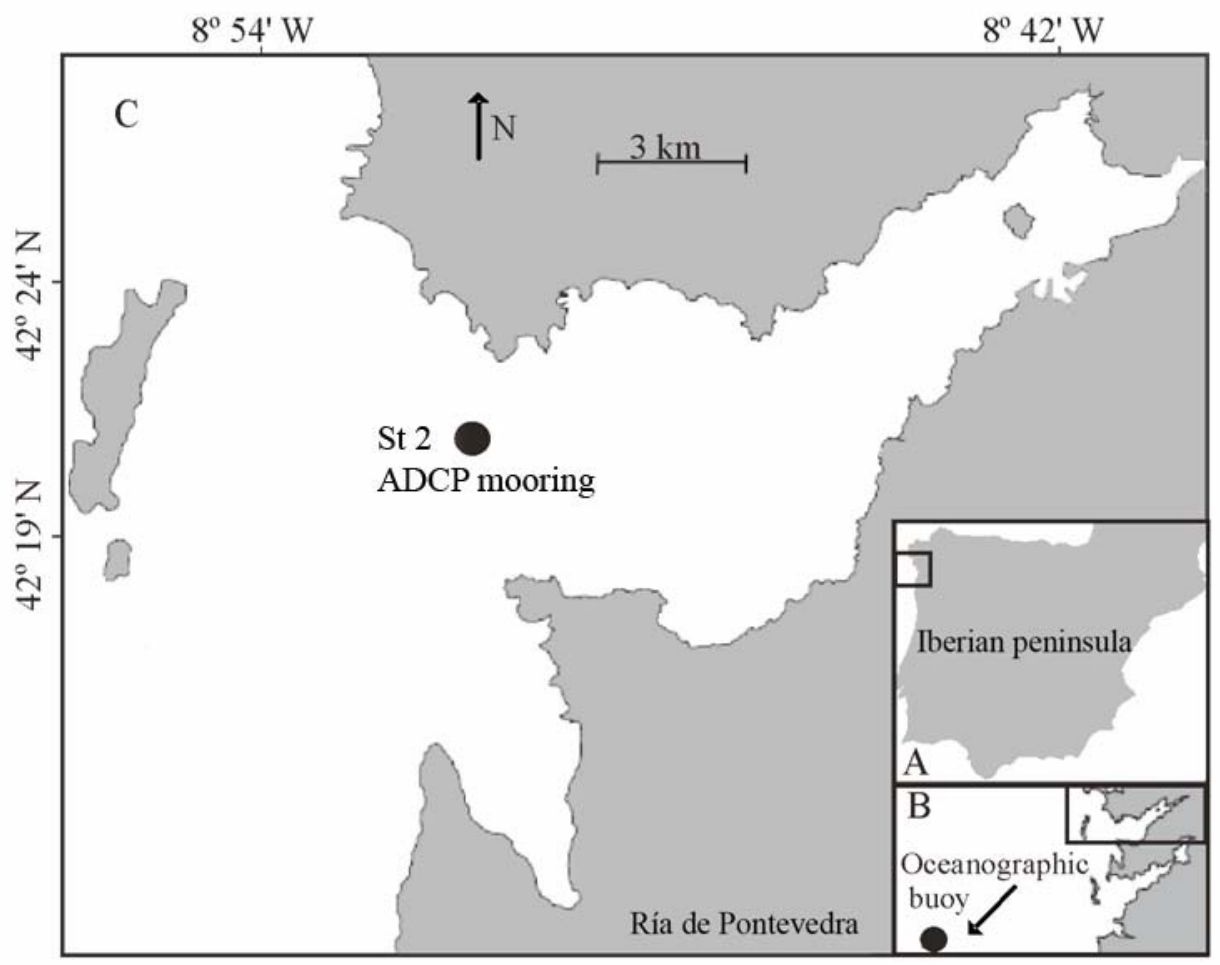

Figure 1

Fig. 1 (A) The Galician Rías Baixas (NW Iberian Peninsula). (B) The Ría de Pontevedra in relation to the Rías Baixas and the location of the Sea watch buoy of Puertos del Estado (www.puertos.es) off Cabo Silleiro. (C) Map of the study area showing location of the station and the ADCP mooring (sta 2). 

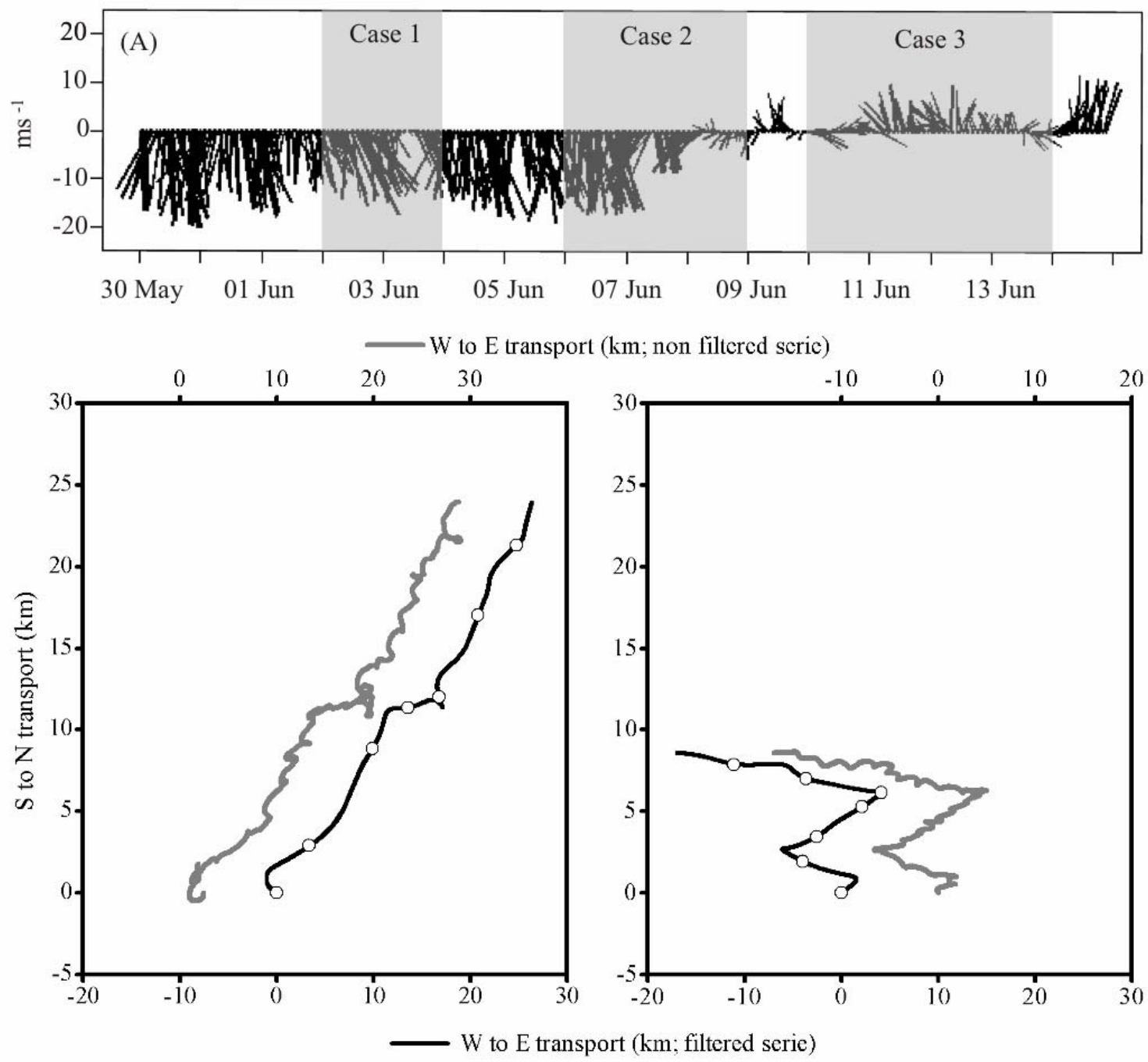

Figure 2

Fig. 2 (a) Stick diagram showing hourly measurements of wind direction and velocity $\left(\mathrm{m} \mathrm{s}^{-1}\right)$ recorded at the Sea watch buoy in Cabo Silleiro (420 7.8' N, 90 23.4' W) between 30 May and 14 June (negative values correspond to northerly winds). (b-c) Progressive vector diagrams of low-pass filtered (black lines) and non filtered (grey lines) current data from the moored ADCP at $10 \mathrm{~m}$ (b), and $40 \mathrm{~m}$ (c) depth from 30 May to 14 June. Data start at the origin $(0,0)$. Dotes are positioned at midnight each $48 \mathrm{~h}$ and arrows point the end of the periods: Case 1 (03 June), Case 2 (08 June) and Case 3 (13 June). 

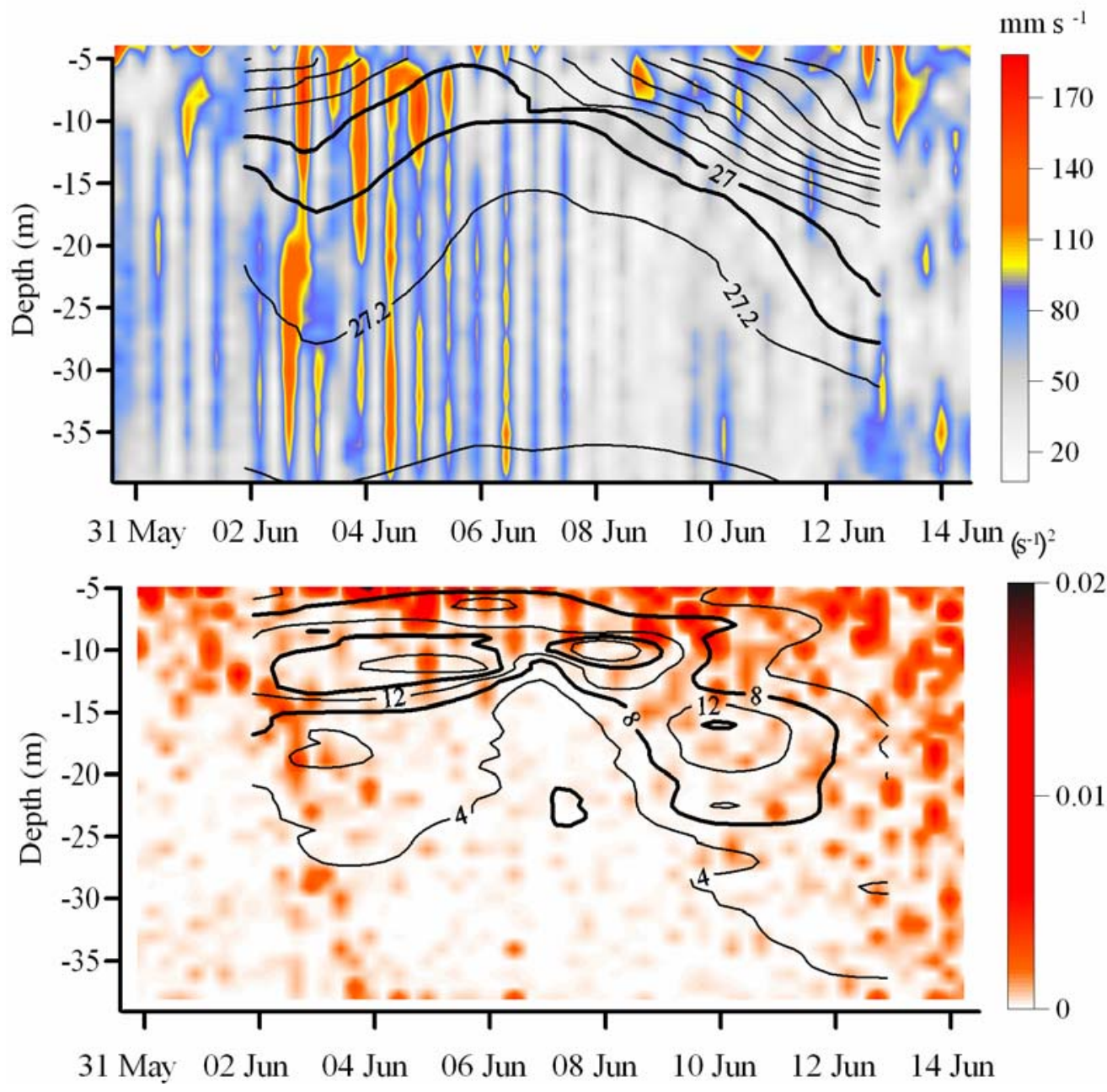

Figure 3

Fig 3 Vertical distribution, from 02 to 13 June, of (a) water current velocity ( $\mathrm{m} \mathrm{s}^{-1}$ ) and (b) shear squared $\left(\mathrm{s}^{-1}\right)$ as coloured background; and (a) seawater density (27 and 27.1 $\sigma_{\mathrm{t}}$ isopycnals) and (b) Chl a concentration ( $\left.\mu \mathrm{g} \mathrm{Chl} \mathrm{L} \mathrm{L}^{-1}\right)$ as contour lines. 

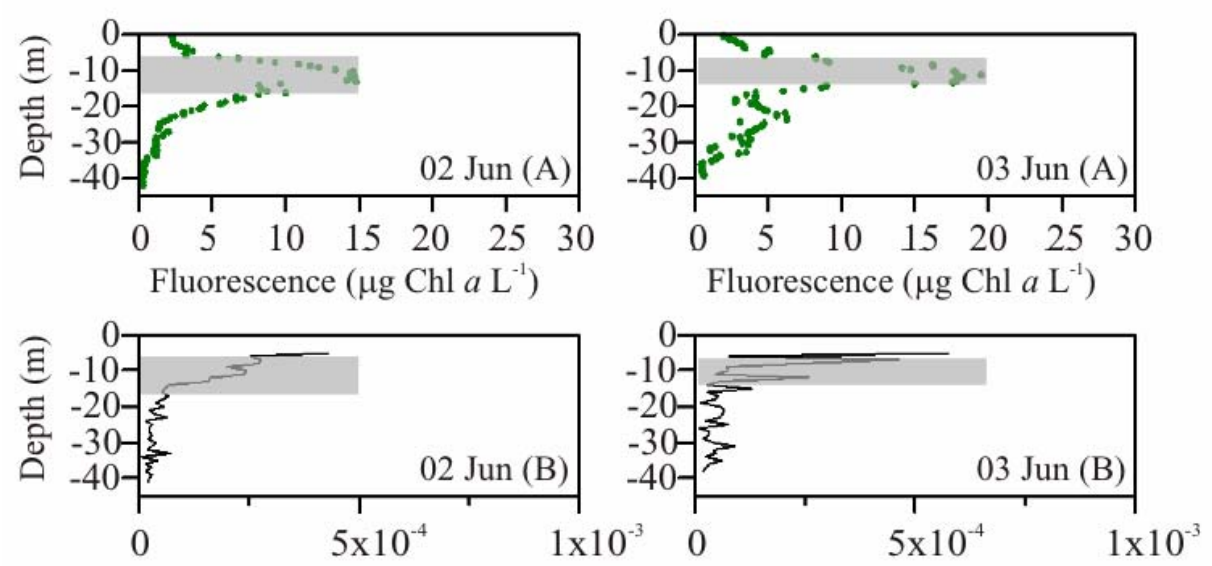

Buoyancy frequency $\left(\text { radians } \mathrm{s}^{-1}\right)^{2}$

Buoyancy frequency (radians s $\left.{ }^{-1}\right)^{2}$
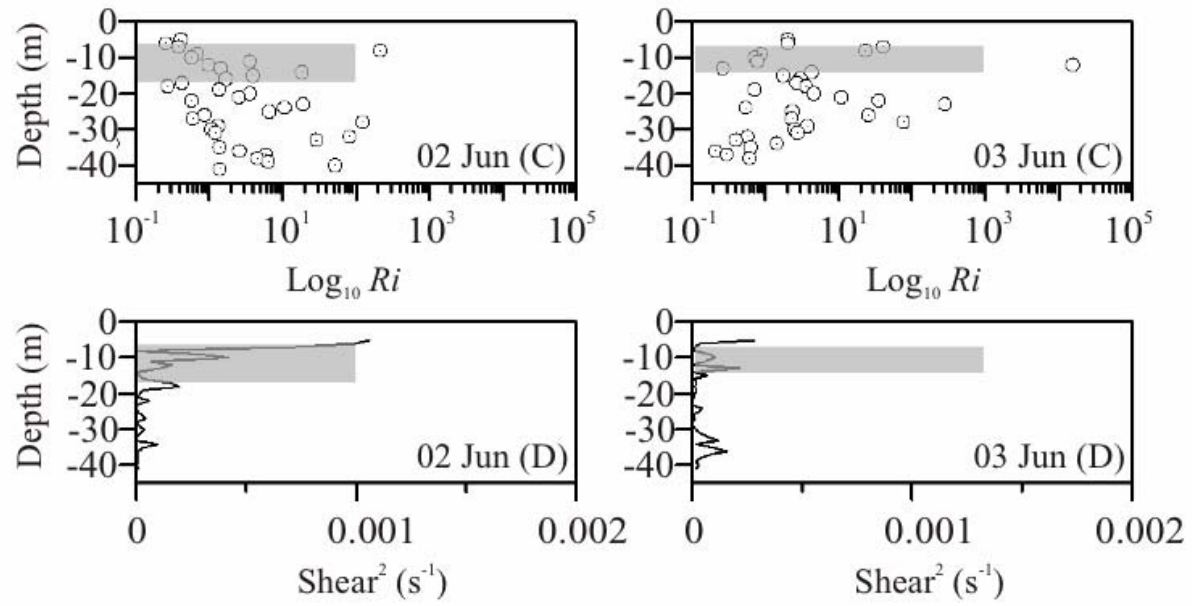

Figure 4

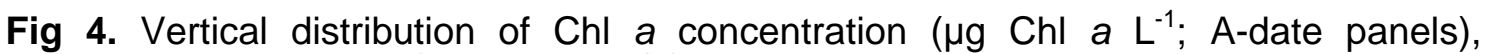
buoyancy frequency $\left(\mathrm{N}^{2} \text {; (radians } \mathrm{s}^{-1}\right)^{2}$; B-date panels), Richardson number (Ri; log scale, C-date panels), shear squared ( $\mathrm{s}^{-1}$; D-date panels) at station 2 in the Navigation Channel of Ría de Pontevedra from 02 - 03 June (Case 1) 2005. Depth range of the $\mathrm{Chl}$ a structure found is shaded 

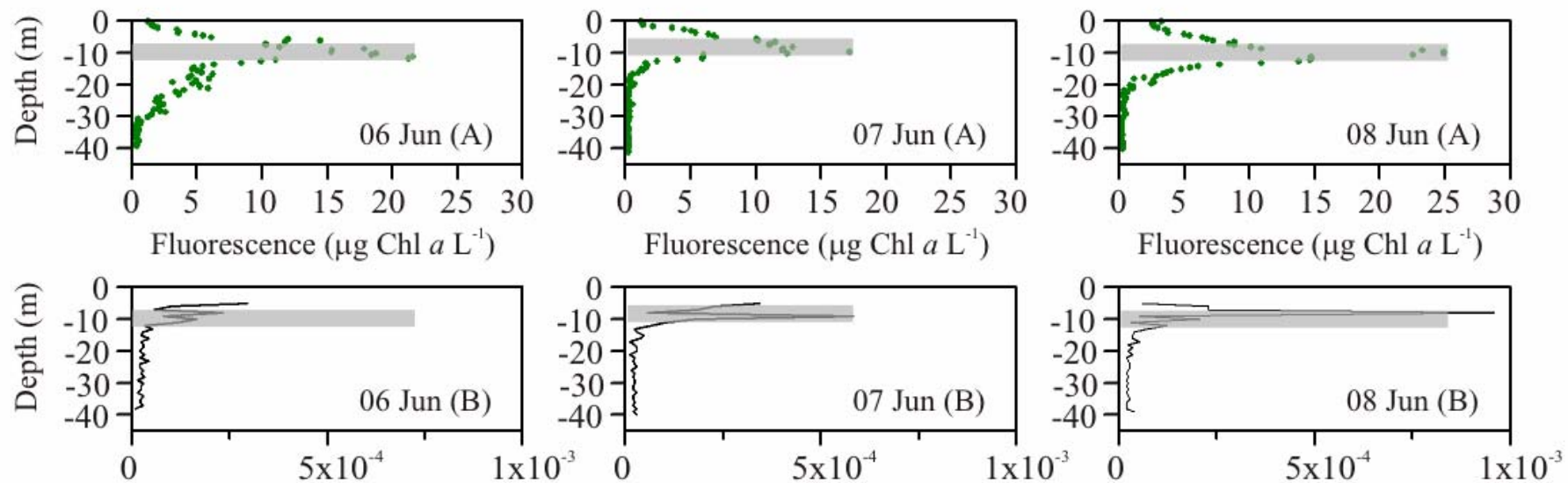

Buoyancy frequency (radians $\left.\mathrm{s}^{-1}\right)^{2}$

Buoyancy frequency (radians s $\left.{ }^{-1}\right)^{2}$

Buoyancy frequency (radians $\left.\mathrm{s}^{-1}\right)^{2}$
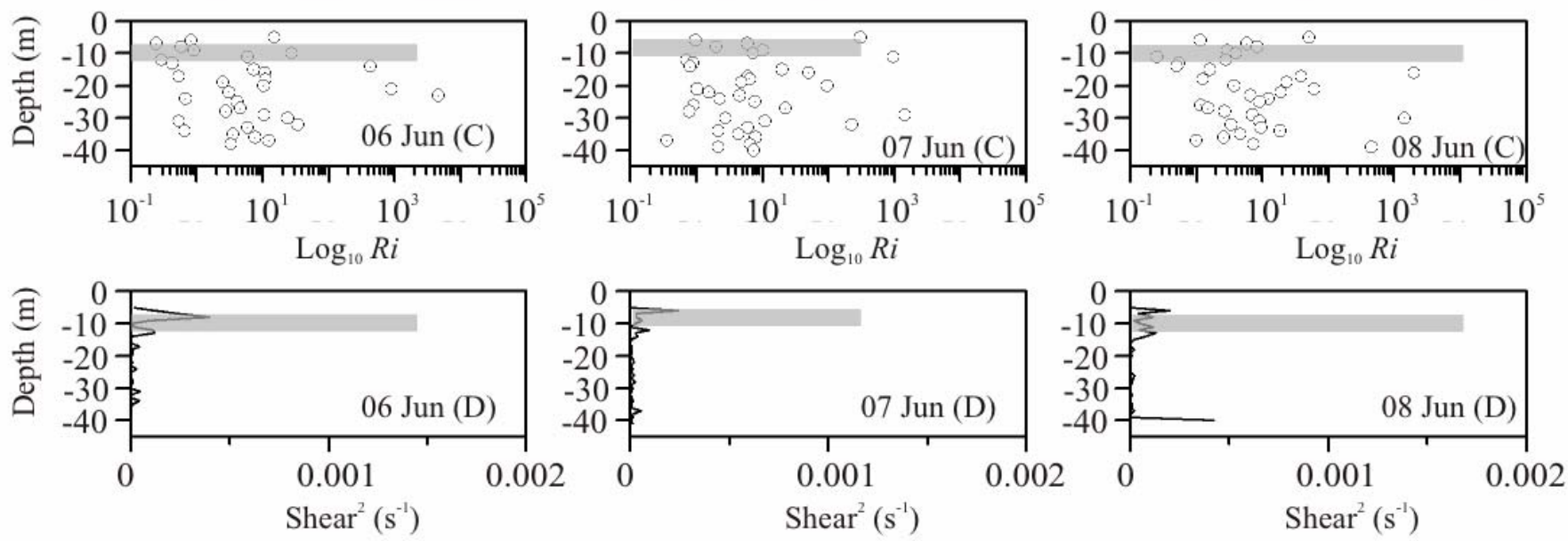

Figure 5

Fig 5 Vertical distribution of $\mathrm{Chl}$ a concentration ( $\mu \mathrm{g} \mathrm{Chl} \mathrm{a} \mathrm{L}^{-1}$; A-date panels), buoyancy frequency $\left(\mathrm{N}^{2} \text {; (radians } \mathrm{s}^{-1}\right)^{2}$; B-date panels), Richardson number (Ri; log scale, C-date panels), shear squared ( $\mathrm{s}^{-1}$; D-date panels) at station 2 in the Navigation Channel of Ría de Pontevedra from 06 to 08 June (Case 2) 2005. Depth range of the Chl a structure found is shaded. 

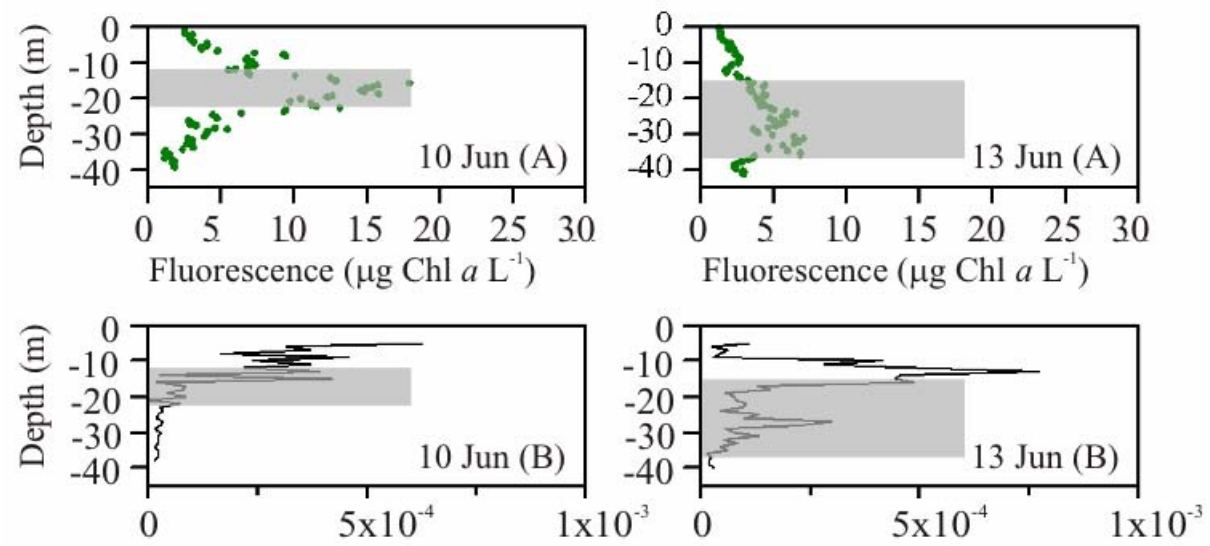

Buoyancy frequency (radians s $\left.{ }^{-1}\right)^{2}$

Buoyancy frequency $\left(\text { radians } \mathrm{s}^{-1}\right)^{2}$
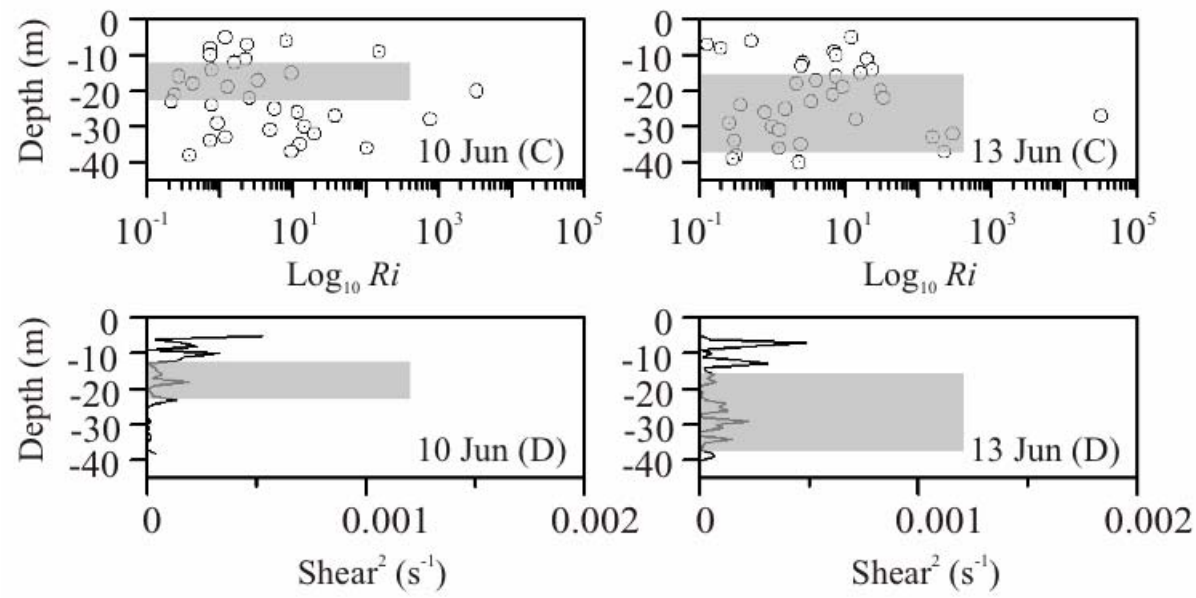

Figure 6

Fig 6 Vertical distribution of $\mathrm{Chl}$ a concentration ( $\mu \mathrm{g} \mathrm{Chl} \mathrm{a} \mathrm{L}^{-1}$; A-date panels), buoyancy frequency $\left(\mathrm{N}^{2} \text {; (radians } \mathrm{s}^{-1}\right)^{2}$; B-date panels), Richardson number (Ri; log scale, C-date panels), shear squared ( $\mathrm{s}^{-1}$; D-date panels) at station 2 in the Navigation Channel of Ría de Pontevedra from 10 - 13 June (Case 3) 2005. Depth range of the $\mathrm{Chl}$ a structure found is shaded. 

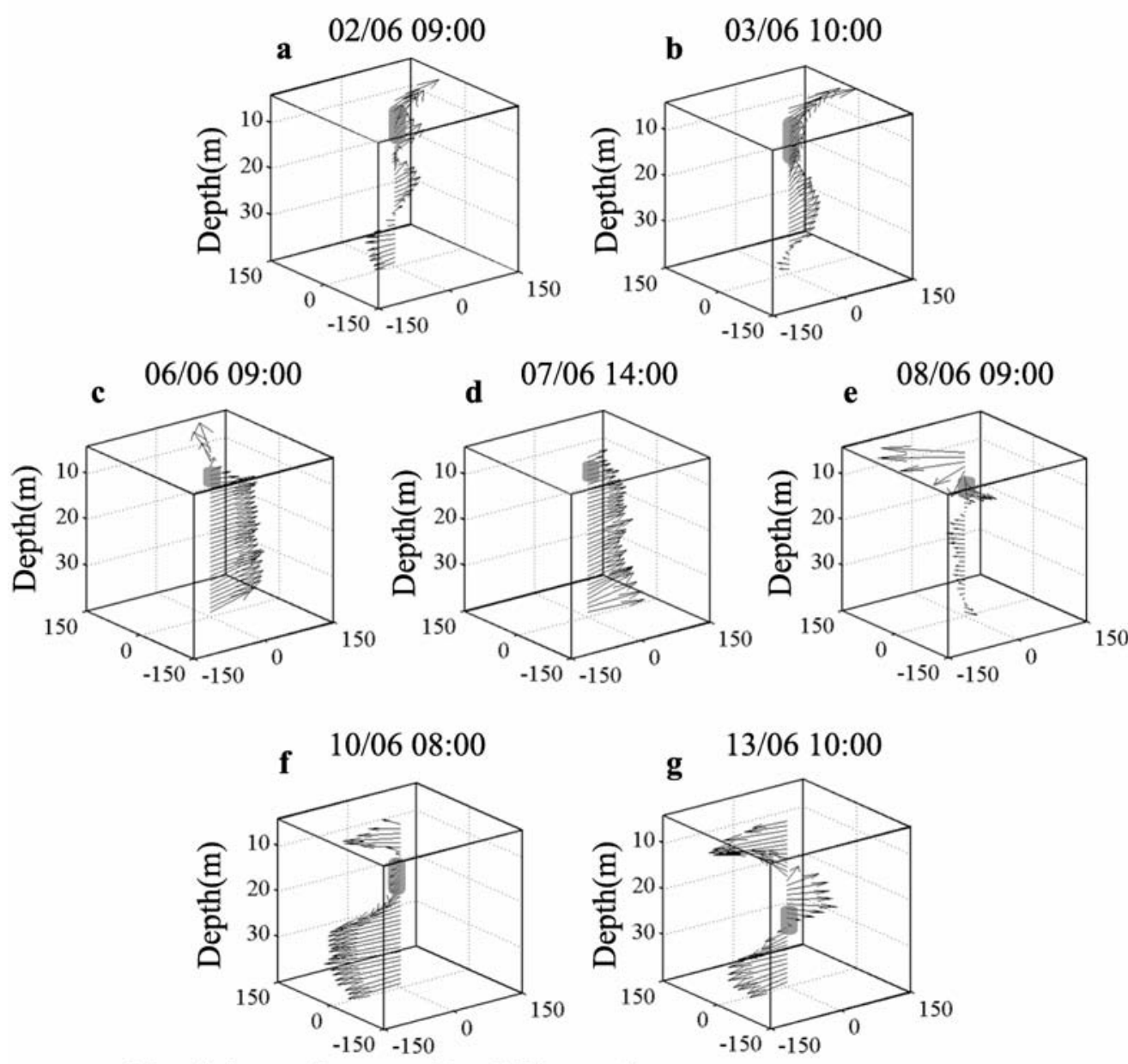

$\mathrm{N}$ to $\mathrm{S}\left(\mathrm{mm} \mathrm{s}^{-1}\right) \quad \mathrm{E}$ to $\mathrm{W}\left(\mathrm{mm} \mathrm{s}^{-1}\right)$

Figure 7

Fig 7 Spatial coincidence between the chlorophyll maximum and changes in the direction of horizontal current velocity. Velocity profiles are represented as vectors; chlorophyll maxima vertical ranges are shown by shaded bars. The day/month and hour of each sample is note. 